\title{
The Use of the [ts] Variant in the Arabic Bedouin Dialects
}

\author{
Mahmoud El Salman ${ }^{1}$ \\ ${ }^{1}$ King Faisal University, Saudi Arabia \\ Correspondence: Mahmoud El Salman, King Faisal University, Saudi Arabia. E-mail: el_salman@hotmail.com
}

$\begin{aligned} & \text { Received: November 27, } 2015 \\ & \text { Accepted: December 28, } 2015 \quad \text { Online Published: January 31, } 2016 \\ & \text { doi:10.5539/ijel.v6n1p118 }\end{aligned}$ URL: http://dx.doi.org/10.5539/ijel.v6n1p118

\begin{abstract}
This paper is a sociolinguistic study of the speech of people who belong to Bedouin tribes, namely, the Anizi tribe, in Saudi Arabia. The speech of forty-eight informants from this tribe has been observed and analyzed with the aim of noting variations in the speech of this group and identifying possible correlations with selected extra-linguistic factors. Because the variant $[\mathrm{ts}]$ of the $(\mathrm{K})$ variable is the key feature of the dialect of this group, it will be used as a basis in investigating this variation. The study shows that the /ts/ sound, which is not widely known or used by a large percentage in the Arab world, is still categorically used in the speech of the members of this tribe within the tribe's domain. It frequently appears in a high percentage in the speech of the older generation as well as the young. The study also shows that its use drastically decreases in other settings. Complex psycho-linguistic and socio-linguistic factors have been found to be crucial in determining whether the variant is preserved or abandoned within the different settings.
\end{abstract}

\section{Introduction}

The Anizi tribe is an old, well-known tribe in the Kingdom of Saudi Arabia. The majority of the Anizi people are from the northern parts of the kingdom, such as Araar, Al-Qryyat, and Hafr Al-Batin yet large populations are also found elsewhere throughout the country. Some of them work or study in Dammam or Al-Ahasa, where I was given the chance to meet them and, accordingly, to interview them.

The dialect of this group is one of the very few Arabic dialects in the area which still actively uses the variant [ts] in its phonetic inventory. The paper documents a linguistic phenomenon which is very important to the sociolinguistic debate in Arabic linguistics. This concerns the variable $/ \mathrm{K} /$ and its variant [ts] which is rarely used in the Arab world. It would not be an exaggeration to say that many native Arabic speakers from different regions have never heard of it. Interviews with thirty native Arabic speakers (including people from the same area as members of the Anizi tribe) demonstrated that $98 \%$ of these interviewees had never heard this sound. It shows the rare possibility of the existence of a variant in the speech of some, yet it is so exclusively used that people living only some kilometers away from the area where it is used, have had virtually no exposure to that variant.

In addition, most of the sociolinguistic studies which have been carried out within the Arab world in which the $(\mathrm{K})$ variable was also studied have never mentioned the /ts/ as one of the possible allophones of the $(\mathrm{K})$ variable. Such allophones have been confined to the boarders of the tribe and used exclusively among its members as a result of some sociolinguistic factors. The use of such sounds outside the perimeters of the tribe might be avoided because it is considered to be a sound that is stigmatized or possibly unknown. In short, the variant is not widely understood. As a result, its use renders common words totally indecipherable to Arabic native speakers. The words simply were not recognized when pronounced with the /ts/ sound. Examples of these words collected from the face to face interviews are: /shantitits/ (/shantitik/) "your bag;" /kiif halits/ (/kiif halik/) "how are you;" and many others.

The study shows that the velar is realised as [ts] most often near front vowels. This is indicated in the following data below taken. The data also show that the $/ \mathrm{k} /$ can be realised as $/ / \mathrm{ts} /$, word-initially, word-finally and word-medially. 
The following are examples of when it is used word-finally:

$\begin{array}{llll}\text { /ya zinik/ } & \rightarrow & \text { /ya zinits/ } & \text { "how beautiful you are" } \\ \text { /kiif halik/ } & \rightarrow & \text { tsiif halits/ } & \text { "how are you" } \\ \text { /kitabtik/ } & \rightarrow & \text { kitabits/ } & \text { "your book" } \\ \text { /hadak/ } & \rightarrow & \text { /hadats/ } & \text { "your limit" } \\ \text { /bitnik/ } & \rightarrow & \text { /bintits/ } & \text { "your daughter" }\end{array}$

The following examples indicate that the [k] can also be realised as [ts] word-medially:

$\begin{array}{ll}\text { /yifakir/ } & \rightarrow \text { /yifatsir/ "he thinks" } \\ \text { /bakito/ } & \rightarrow \text { /batsito/ "you made him cry" } \\ \text { /yakwi/ } & \rightarrow \text { /yatswi/ "iron" }\end{array}$

The following examples illustrate when the $[\mathrm{k}]$ is realised as [ts] word-initially:

$\begin{array}{llll}\text { /kiif/ } & \rightarrow & \text { tsiif/ } & \text { "how" } \\ \text { /kalb/ } & \rightarrow & \text { tsalb/ } & \text { "dog" } \\ \text { /kaf/ } & \rightarrow & \text { tsaf/ } & \text { "palm" } \\ \text { /kabiir/ } & \rightarrow & \text { tsabiir/ } & \text { "big" }\end{array}$

Moreover, the data also show the possibility of words in which the /ts/ is used word- medially and word-initially:

/Kankan/ $\rightarrow$ / tsantsan/ "hesitate"

Thus, the velar $/ \mathrm{k} /$ can be realised as [ts] in every possible context in the dialects of the informants.

\section{The (K) Variable}

In general and in most of the studies of the Arab world (see Abdel Jawad, 1981; Al Khatib, 1988, El Salman, 2003, El Salman, 2008) which investigate the (K) variable, two variants of it, namely, the SA variant $/ \mathrm{k} /$ and the rural variant $/ \mathrm{C} /$, have been mentioned and taken into consideration. In this study, the third variant, which was rarely addressed in other studies in the Arab world and therefore, not classified as a variant, will be the focus of the investigation. Thus, this is a significant study. Accordingly, I can add to the existing research that there are three variants of the $(\mathrm{K})$ variable. These are the voiceless velar stop $[\mathrm{K}]$, the voiceless alveo-palatal affricate $[\mathrm{C}]$, and the voiceless dental affricate [ts]. It is also worth noticing that the two sound changes ki- kiš and ki- $\breve{s}$ come under the umbrella of kashkasha in works of the Arab grammarians (Watson, 1992).

According to Sibawayhi, many people from the Tamim and Usd tribes, two ancient Arab tribes, used to pronounce the velar $/ \mathrm{k} /$ of the second person feminine singular pronoun suffix as $[\mathrm{C}]$ in order to distinguish between the feminine and the masculine (Sibawayhi; cited in Qasim and Khaleel, 1996). This view is supported by Al-Azraqi (2104). According to the later, the explanation that Sibawayhi advances for this change is that the speakers wanted to make a distinction between males and females when addressing them. The Classical Arabic reference to a male person is $/ \mathrm{ka} /$, and both feminine $/ \mathrm{ki} /$ and masculine $/ \mathrm{ka} /$ lose their final vowel in pause, so that the distinction between the two genders disappears there. Sỉbawayhi adds that the speakers select $/ \check{\mathbf{s}} / \operatorname{since}$ it is a voiceless sound, just like /k/, e.g. 'inniš dַāhiba "you [fem.] are leaving”; māliš dַāhiba "why are you [fem.] leaving?", instead of 'innaki and mālaki (Al-Azraqi, 2014).

Holes (1991) rejects this view. He claims that $-\mathrm{k}$ (masc) -ki (fem) was the first stage in the reduction of the OA system in the peninsula. According to him, the subsequent shift of $\mathrm{OA}-\mathrm{ki}$ to (i)č and then -(i) č have nothing to do with maintaining a gender distinction which was already assumed by the absence or presence of a final $-\mathrm{i}$, as in the perfect verb. It can be explained as a natural phonological change which first fronted and affricated/ $\mathrm{k} / \mathrm{in}$ high front vowel environments, and which later spread to low front vowel, as well (Holes, 1991, p. 660). He also states that the original $\mathrm{OA}-\mathrm{ka}$ (masc.) i-ki (fem) distinction was matched by a similar final sjort vowel contrast in the perfect verb: daraba (you (masc) hit), darabti (you (fem.) hit). In virtually all Arabic dialects, this evident redundancy in the verb morphology was reduced by making the masculine the unmarked form through the dropping of final $-\mathrm{a}$ (darabt) and retaining the OA final short vowel marking of the feminine form (darabt) (Holes, 1991, p. 660).

Watson also discusses the possibility that kashkasha might emerge in order to preserve "the kasra of ki in pause", as is claimed by Arab grammarians and by some European commentators. According to Watson, kashkasha and kaskasa are both considered by Arab grammariants to occur in consequence of restrictions on vowels in pause 
(Watson, 1992, p. 64). She adds that "kaskasa receives less mention than kashkasha and is said to be either the affixation of sin to kaf al-mu?nanath in pause . . . or, and more rarely, the replacement of kaf al mu?annath by $\sin$... which, as in the case of the substitution of shin for kaf, occurs predominantly in pause but is also attested within the phrase" (Watson, 1992, p. 64).

According to Owens, Sibawaih's description of the 2FSG object variants -kiš and -kis has generated a good deal of discussion among Arabists. He adds that some, such as Johansotone (1963) have identified them with the contemporary affricated variants -tš and ts. Owens thinks that the two variants, kiš and -kis are identified with the modern variants, tš and ts, respectively (Owens, 2013). Owens states that the 2FSG variants from Sibawaih's viewpoint can be realized as the following:
a. - ši
b. Kiš
c. Kis
d. $\mathrm{Ki}$

Owens also points out that modern dialects have four basic variants of the 2FSG object suffix:

a. -iš highland yemen, eastern Arabian Peninsula

b. -Its Najdi

c. Ič [itš] Gulf, "gilit” Iraqi. Jordanian and Syrian desert, rural Palestinian

d. -ik or -ki otherwise in the Arabic speaking world.

It is also worth mentioning that in some areas in the southern parts of Jordan, namely Karak city, there is another variant used in order to differentiate between male and female object (El Salman, 2003). The 2FSG used for this purpose is ki. In other words, neither Ič [itšc], as Owens mentioned, nor is /ik/ used in this area. As an example, people in this area say:
a. Kiif halki
"how are you"
b. Axtki
"your sister"
c. Bintki
"your daughter"

In other areas where some Bedouin tribes live, namely Bani Sakhir tribe, the /ts/ sound is also used. But it is exclusively used among the members of this tribe in the villages where they live, namely, Hwara, Um al Risas and um al Amad.

Holes, according to Owens, points out that the change of $/ \mathrm{k}$ to $\check{c}$ or ts extends beyond the 2FSG suffix to front vowel contexts generally where $/ \mathrm{k} /$ precedes a front vowel, either $/ \mathrm{i} /$ or front $/ \mathrm{a} /$ (Owens, 2013). E.g. čaan/tsaan "he was". This general conditioned change is paralleled by the change of g to dž/dz, e.g. ğiddam "in front", dziddam.

Holes (1991, p. 653) tries to show the distribution of the reflexes of OA -ki in modern Arabia. Accoring to Holes:

(a) (i) š is a southern feature. "It is normal dialectal reflex in the north and east of North yemen, and the whole of southern Arabia, with pockets extending as far as north as al-Hasa [where my study is conducted] and Bahrin". The northern border of the solidly - (i) $\breve{s}$ area is formedby the edge of the najd plateau and its western limit is a line which follows the edge of the Asir mountain range, ending slightly to north of Arabia.

(b) The Yemini in central and north-central Arabia the reflex is a dental affricate -(i) č (IPA [ts]). The extreme south west limit of the -(i) č area at Bisha. It extends north through central Najd, Qasim, Jabal Shammar and far north as Shamari groups in the deserts of N. Syria. This č is a central feature, normal throughout central Arabia

(c) In the Syrian desert either side of the -(i) č area, throughout lower Iraq and khuzistan, and the length of the eastern Gulf littoral as far as Dubai, the reflex is an alveolar affricate - (i0 č (IPA [t\$].

Holes also believes that a palatalization of $\mathrm{k}$ to š occurred in the south Arabian languages at some distant point in the past (Holes, 1991, p. 663).

Al-Rojaie points out, given the findings of his study, that adjacency to high and low front vowels contribute statistically significant effects to [k] affrication. According to him, affrication of [k] is most highly favoured by adjacency to high front vowels with a relative weight of .92, followed by low front vowels .62, whereas it is not favoured when there are no front vowels. .09 very strongly (only $2 \%$ affrication in this environment) (Al Rojaie, 
2006, p. 51).

The results also showed an age pattern suggesting a language change was in progress; older speakers were more likely to affricate and the young were less likely while the middle-aged speakers fell in between. This is very similar to the results regarding the use of the /ts/ in our study; the older the informant is, the higher the chance of its occurrence in his or her speech. It is also similar to our study with regard to the use of affrication in a non-local group; in our study we focused on the city of Karak in Jordan (El salman, 2003a). We found that 71\% of the speakers belong to the older age group. These findings were expected as the variant $[\mathrm{C}]$ is perceived as rural and, to a great extent, is related to the dialect of the older members of a community (Abdel-Jawad, 1881; $\mathrm{Al}$ Khatib, 1988; El Salman 2003a). Al Khatib reports that "the variant [C] is a highly stigmatized feature in the city . . . and most of the Jordanian people in Irbid City disfavour it (Al Khatib, 1988, p. 236)." Abdel Jawad also reports that "speakers are aware of this stigmatized feature more than any other feature and they try their best to avoid using it in their speech, especially in front of strangers (Abdel Jawad, 1981, p. 279)."

Unexpectedly, the $[\mathrm{C}]$ has been found to have a new connotation and a new social meaning, which is perceived positively in other studies, including my study in Tubnih (Jordan). In our study, affrication has been found to have an unexpected new social meaning when it comes to the new generations and among the youth. The study shows that the $[\mathrm{C}]$ variant of the $(\mathrm{K})$ variable occurs in $87 \%$ of elderly male's utterances and $90 \%$ of elderly women's utterances. It also shows that the [C] variant is used in $9 \%$ of female speakers in the middle aged group and $30 \%$ of male speakers. Among the younger population, its occurrence was $35 \%$ among young male informants and $2 \%$ among young female informants. Thus, it is evident that there was a decline in the use of the [C] variant but the trend later began to reverse; it was $30 \%$ among the middle aged group but then increased to $35 \%$ among the young (El Salman, 2008).

In my attempts to find an explanation for this reversal in trend which demonstrated a 5\% increase in the use of [C] from the middle aged group to the younger group, I found that it is linked to a new tendency among the young to appear as local. They seek to confirm their localness by making the shift in their speech by using this stigmatized variant more than the middle aged group. It was apparent that Scotton's "cost and reward" principle operates here. Appearing as local provides access to power which is the "reward" and is more important than not appearing as prestigious which is the "cost."

The $[\mathrm{g}]$ variant of the $(\mathrm{Q})$ variable was used as a symbol of local Tubnih identity. But we think that the $[\mathrm{g}]$ variant has become the stereotype variant among males in Jordanian community. Indeed, the $[\mathrm{g}]$ has even become frequent among individuals who migrated to the area and who were originally urban. As such, it has become impossible to identify local people who wish to appear as local and distinguish them from immigrants who have adopted the $[\mathrm{g}]$. As a result, the local [C] variant which has been found to be abandoned in favour of the $[\mathrm{k}]$ variant has been taken up quickly among the local people as another tool to confirm their localness. In other words, a high percentage of $[\mathrm{C}]$ is also linked with a strong tendency to be distinguish oneself from the non-locals who have begun to adopt the $[\mathrm{g}]$ which has become a stereotypical regional linguistic feature used categorically by young male speakers regardless of their origins (El Salman, 2008) Milroy and Milroy point out that young males "appear to favor more localized variants, which carry some kind of identity-based social meaning in the local community (Milroy and Milroy, 1997, p. 55)."

In terms of affrication among gender groups, men appear to favour its use more than women do. This finding is not surprising as females, in general, "favour prestige norms" (Milroy, 1987, p. 55), and the [C] is perceived as the stigmatized variant. Al Khatib reports that "the variant $[\mathrm{C}]$ is a highly stigmatized feature in the city ... and most of the Jordanian people in Irbid City disfavour it" (Al Khatib, 1988, p. 236). Abdel Jawad also reports that "speakers are aware of this stigmatized feature more than any other feature and they try their best to avoid using it in their speech, especially in front of strangers (Abdel Jawad, 1981, p. 279)." Thus, for the affrication to be less frequent among females is to be expected.

I am of the opinion that the members of the Bedouin tribes articulate the [k] sound as [ts] in order to strengthen this difference between male pronoun and female pronoun as in the following examples: /kiif halak/ "how are you?" (masculine) and /kiif halits/ "how are you?" (feminine). It should also be noted that the /ts/ sound replaces the $/ \mathrm{k} /$ sound in other words as well although they are not used to address males or females.

Thus, it could say that lexical diffusion theory is applicable in this case as it helps to interpret how a change spreads internally within the language. In other words, the change starts with words containing the variable $/ \mathrm{k} /$ which is replaced by /ts/ when addressing females. Later this change is observed in other words that also contain the variable $/ \mathrm{k} /$ regardless of the gender of the person(s) being addressed. In the following words, the variable $/ \mathrm{k} /$ is not part of a female pronoun but has nonetheless been pronounced by the informants as /ts/: /ibtsi/ (/ibki/) 
"cry;" /tsiif/ (/kiif/) "how;" and /tsnah///ka'nah/) "as if it is." Thus, the process began with an effort to distinguish between male and female pronouns by means of the variable $/ \mathrm{k} /$. However, as we have seen, this unique adaptation later becomes interspersed in the vernacular of the tribe members through its use in more neutral words containing the variable $/ \mathrm{k} /$ without the feminine pronoun. In other words, a change spread internally within the language. The /ts/ sound in these words is now a part of the word and not simply a feminine pronoun.

This explains how a sound change within a language takes place. By allowing the change in some linguistic context, it then becomes permissible to allow it in other similar contexts. The process begins with a linguistic aim (to differentiate between the forms for addressing males and females), and, as a consequence, it becomes a habit; the $/ \mathrm{k} /$ variable is essentially recognized as $/ \mathrm{ts} /$ in other words and contexts.

In its standard configuration, well known in countries such as Saudi Arabia and Jordan, the variant $[\mathrm{k}]$ is profiled for higher register, formality, and education whereas the variant [ts] is ethnically specific or associated with local prestige within the tribe. In using the local variant, a member of the tribe thereby exudes a sense of belonging, a feeling that I am one of "YOU", a member of the group, as expressed by one of the informants. This gives the individual prestige within the tribe.

Nonetheless, this does not have the same effect outside the tribe because it does not confirm locality. This is because it is associated with a particular local group, but it is not used by the vast majority of the larger population of the region. The informants confirmed this after their formal interviews; they do not use the variant [ts] with other people outside of their tribe because they feel that they will not be understood. In fact, to be a particular "who" and to pull off a particular "what" requires that we use language in sync with or in coordination with other people in appropriate locations and at appropriate times (Gee, 1999). In other words, the use of this specifically local sound aids the members of the tribe in identifying each other as "true Anizians". In addition, Wieder and Prat point out that language is a suitable tool to use in order to appear as real members of a given group, and it would be enough for some tribal men to refer to persons who belong to their groups in just those words with regularity (Wieder \& Prat, 1990a).

\section{Methodology}

The study is empirical in its method in that it is fully dependent on naturalistic speech. All the interviews, which were conducted in Saudi Arabia, used the face-to-face technique for obtaining data with regard to linguistic variation. The study comprises citizens of Saudi who originally stem from the Anizi tribe. The size of the sample is acceptable and comparable to the number of informants in many similar studies. For example, Tradgill's 1974 study consisted of sixty informants in a city with a population of 118, 610, and Daher's 1998 study, conducted in Damascus, focused on forty-six informants. Labov also notes that "the structure of social and stylistic variation of language can be studied through samples considerably smaller than those required for the study of other forms of social behavior (Labov, 1966, p. 638)."

The large social network made it possible to draw the sample from different kinds of people and from both sexes. Nonetheless, It is to be confessed that because the society of the study is conservative, it was not possible to personally conduct interviews with female informants. This is a very problematic issue in the Arab world because of the cultural norms restricting women's contact with men. It has led some sociolinguists to exclude females from their study as in the case of Al-Jehani in his study of Makkan Arabic (Saudi Arabia) (Al Jehani, 1985). Fortunately, many of those who I teach were also users of the [ts] variant, and I was given the chance, as such, to hear it as it is actually used within the tribe from some of its native female speakers.

To overcome this obstacle and still include females in the study, I was obliged to engage a female to help me carry out the interviews. Some data were also obtained from female and male students who conducted some of the interviews with their female relatives on my behalf. For this, two female students and two male students were trained to know how the interviews should be carried out.

This study is conducted in light of the Labovian Paradigm. The interviews were carried out in different locations, and some male students and colleagues were interviewed at the university. The social network framework was followed, and the informants were approached in the capacity of "a friend of a friend" or, in some cases, "a friend of a friend of a friend (Milroy \& Milroy, 1978)." Some group conversations were recorded with male students who are members of this tribe. The recorded conversations could be considered "a supplementary check on these face-to-face tape-recorded interviews (Labov, 1972b, p. 13)."

The questions asked in the interviews were designed to provide a challenge for the interviewees' memories in that they depended solely on their personal knowledge of the Anizi tribe or what they remembered hearing from 
their parents about their history. The interviewees' attempts to prove that they remembered more about the village than anyone else overshadowed the attention paid to the linguistic terms used to describe their memories. This, it is believed, helped in "[solving] the Observer's Paradox, and [reducing] attention paid to language (Labov, 2001, p. 36)." Thus, it could be claimed that at least in the majority of the interviews it was possible to know "how [Anizi] talk when they are not being systematically observed (Labov, 1972a, p. 181)."

The sample were divided into three groups based on education, sex, and age. In order to gain a statistically accurate view of the use of the variables, a univariate analysis is employed. For the purpose of using the univariate analysis each group is presented a number. Groups representing level of education are given two numbers. The uneducated group is given number 1 and the educated group number 2 . The male group is given number 1 and female group number 2 . The young age group is 1 , the middle age group is 2 and the old 3 .

\section{4. (K) Variable Used by Anizis in Saudi Arabia: Findings and Discussion}

Table 1 . The distribution of the variable $(\mathrm{K})$ by age and sex

\begin{tabular}{|c|c|c|c|c|c|c|c|c|}
\hline \multirow{2}{*}{$\begin{array}{l}\text { Sex } \\
\text { Age }\end{array}$} & \multicolumn{4}{|l|}{ M } & \multicolumn{4}{|l|}{$\mathbf{F}$} \\
\hline & [ts/in] $\%$ & [ts/out] $\%$ & [k/in]\% & [k/out] & [ts/in]\% & [ts/out] $\%$ & [k/in]\% & [k/out] \\
\hline Young & 90 & 20 & 10 & 80 & 90 & 10 & 10 & 90 \\
\hline Middle & 95 & 60 & 5 & 40 & 92 & 35 & 8 & 65 \\
\hline Old & $99 \%$ & 99 & 1 & 1 & 98 & 99 & 2 & 1 \\
\hline
\end{tabular}

\section{5. /ts/ Preservers}

The members of this group who retain frequent use of the [ts] variant will be called [ts]-preservers. These people are not affected by the strong SA variant $[\mathrm{k}]$, which is largely used in the area. Given the fact that the linguistic behavior of the members of this tribe differs drastically depending on their social context (i.e., inside the domain of the tribe or outside of it), I will deal with their linguistic behavior, accordingly, separately. Thus, Table 1 shows the result of the use of the variant /ts/ inside the tribe, and it also shows the percentage of its use outside the tribe.

Table 1 shows that the [ts] variant is used in $99 \%$ among elder males and $98 \%$ among elder females of the total number of occurrences of the $(\mathrm{K})$ variable inside the tribe. The same percentages were found when dealing with other people outside the tribe. Thus, the context does not play any significant role in the speech of the elder members of the tribe as the [ts] variant occurs with the same percentage both inside and outside the tribe.

This is also shown in figure one and two below. Figure 1 shows that the elderly use the /ts/ variant outside the tribe in a high percentage.

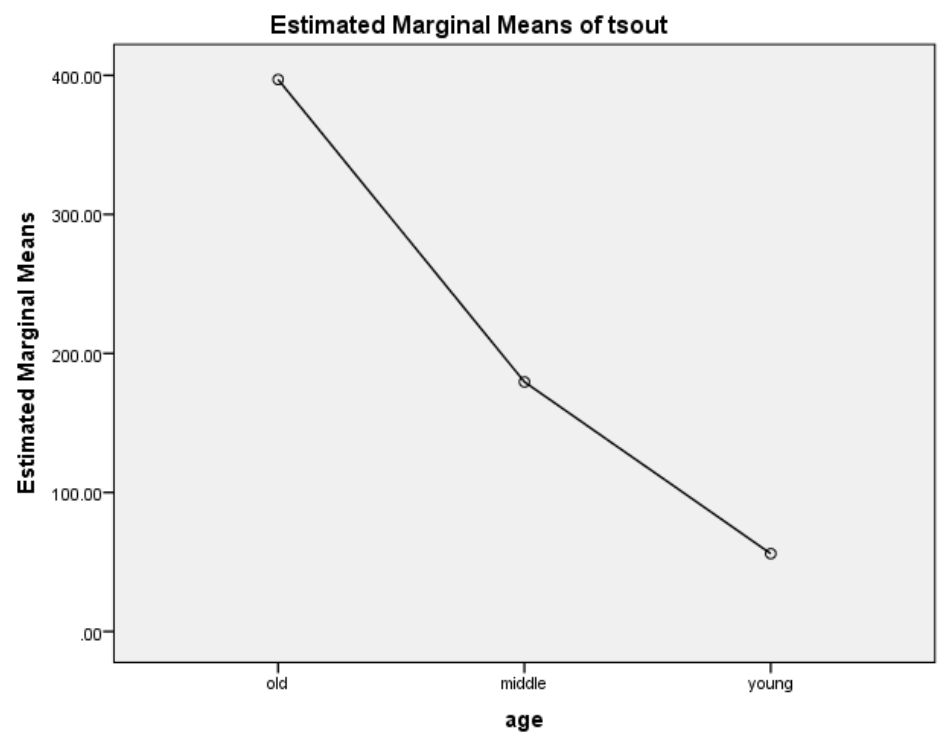

Firgure 1. The use of the /ts/ variant by the elderly 
Figure two also shows that the /ts/ is used in a very high percentage inside the tribe by the old, as well.

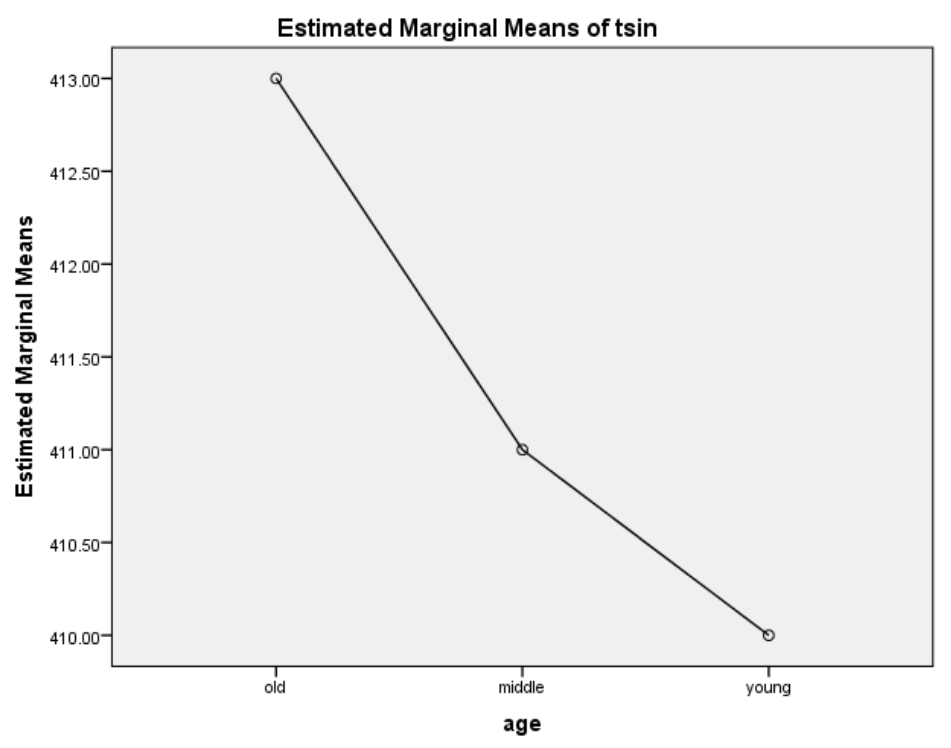

Figure 2. The use of the /ts/ inside the tribe by the old

It can be assumed that the older generation tends to be preservers of old forms, and as a result, they are expected here to be preservers of the /ts/ variant. More than any other age-groups, the older population of an ethnic group is subject to social pressure to appear conservative. In addition, they grew up speaking this way and continued so throughout their lives, and, thus, it is much harder for them to change their speech habits. Le Page states that an individual's tendency toward language shift is constrained by four factors, among which is age (Le Page, 1997). According to Le Page, "[i]ndividuals create their linguistic systems so as to resemble those of the group or groups they wish from time to time to be identified with or so as to distinguish themselves from those they wish to distance themselves from. Their success in doing so is subject to constraints ... [such as] the strength of their motivation, which is likely to be multidimensional; and their ability to change their behavior - possibly mainly a function of age (Le Page, 1997, pp. 28-29)." In addition, Eckert also reports that "community studies of variation frequently show that increasing age correlates with increasing conservatism in speech (Eckert, 1997, p. 157)."

The elders also see little reason to change their speech because they are not concerned with the prestige associated with the variants one employs (see also El Salman, 2003b). They do not make this a priority. As a result, the preservation of this relatively stigmatized variant is supported even if they converse with non-Anizis. In other words, the cost and reward principle does work. According to Myers-Scotton, "a major motivation for using one variety rather than another as a medium of an interaction is the extent to which this choice minimizes costs and minimizes rewards for the speaker (Myers-Scotton, 1995, p. 100)." If this principle is to be considered, succumbing to the pressure of the community to play the role of the preserver of what is old and local in using the [ts] variant would make appearing conservative the reward (Eckert, 1997). Older females behaved similarly with regard to this variant. SPSS statistical analysis also shows that gender is not significant in the use of the [ts] variant among the older generation $(\mathrm{P}<.05$ while $\mathrm{P}<300$ for gender with regard to the use of the [ts] among the older age group).

The middle-aged group members showed almost the same percentage of the use of the /ts/ variant when in the tribe domain, but the percentage of its use decreases when they are in any other domains such as the university, the schools, the city (in this case, Al Ahasa or Al Dammam coastal city). Table 1 shows that the [ts] variant is used in $95 \%$ among middle aged males and $92 \%$ among females of the total number of occurrences of the (K) variable inside the tribe. The percentages were $60 \%$ and 35 found, respectively, when dealing with other people outside the tribe. Many in this age group are employees at banks, universities, and various companies. The nature of these domains requires formality in speech. Thus, the $/ \mathrm{k} /$ variant is appropriate for the setting. The /ts/ variant is very local and, therefore, it must be first determined if its use in a certain setting is suitable or not. The variant itself is part of an intimate code and style which involves a great deal of shared knowledge and background in a private conversation between equals (Mesthrie et al., 2000). 
The most drastic difference between the use of /ts/ inside the tribe and outside the tribe domain is seen in the speech of the young. Table 1 shows that young males use this variant in $90 \%$ of the total number of occurrences of the $(\mathrm{K})$ variable when they are in the tribe domain and are talking to people who also use the /ts/ variant. A similar percentage is also observed in the speech of young females as Table 1 also shows. But its use drastically decreases when they are outside the domain of the tribe. It fell to $20 \%$ in the speech of young males and $10 \%$ in the speech of young females. SPSS statistical analysis also shows that age is significant in the use of the [ts] outside the tirbe $(\mathrm{P}<.05$ while $\mathrm{P}<016$ for gender with regard to the use of the [ts] among the older age group).

Figure 3 also shows this.

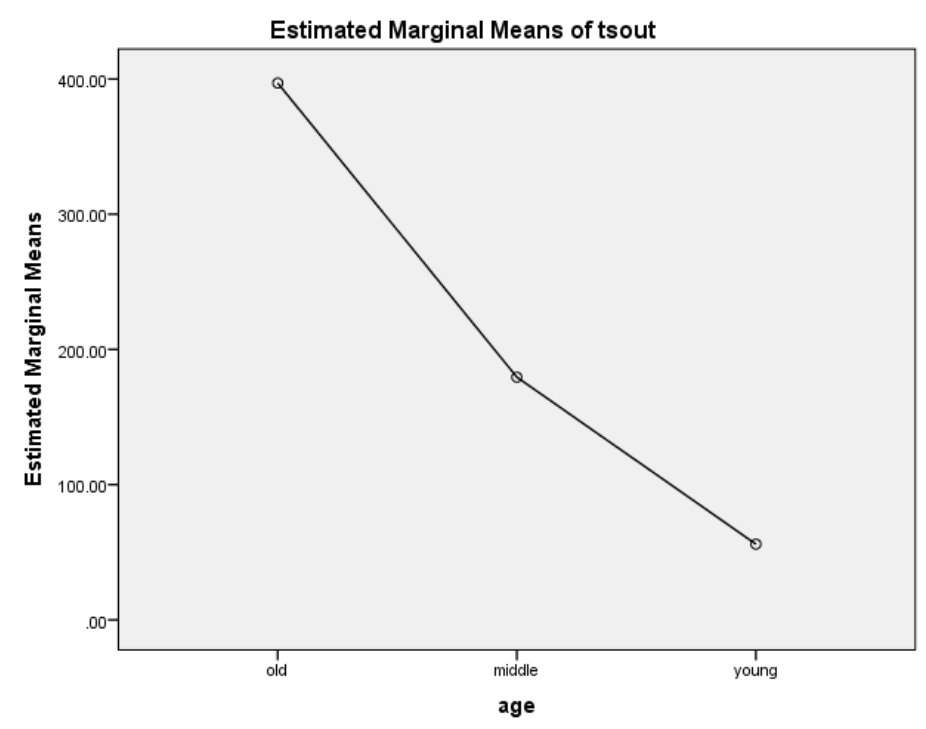

Figure 3. The use of the /ts/variant by age outside the tirbe

Thus, the significant factor in the use of the /ts/ variant in the speech of the young (males and females) is the setting in which they find themselves; the greatest incidents of the use of the [ts] variant occur when they are within the family domain or with people who use it. When they are outside of the family domain with people who do not use it, they rarely include the variant in their speech.

In the personal interviews which took place after the formal interviews, most of the informants stated that they would not be understood if they pronounce words with the /ts/ sound rather than the $/ \mathrm{k} /$ sound because it is not part of their listeners' phonetic inventory. Within the tribe domain, the young use the /ts/ variant to negotiate local identity, but they choose not to use it when negotiating another identity (i.e. being part of the larger Saudi community) when they are outside the tribe domain. Because the use of the /ts/ sound confirms their association with their tribal group, its use can also disassociate them from the larger group, whose phonetic inventory does not include the /ts/ sound. It is a very local sound so it creates intimacy among tribe members but is not understood in the non-local context, so it is avoided.

Both gender groups of the young are ambitious and endeavoring to create a better future. Their actions are, therefore, influenced by any factor that can help them achieve this. Young males strive to conform as much as possible within the larger community. Thus, it becomes obligatory for them to adopt the linguistic form which facilitates being integrated in this dominate group. Young females strive to appear very feminine. Most of the studies show that young women want to use the linguistic form which helps them appear as prestigious and urbanized as possible. In other words, to achieve this, it is not only what you say which is important, but also how you say it.

\section{Conclusion}

This study addresses the use of the voiceless alveolar affricate /ts/ in the dialect of the Anizi tribe, a Bedouin tribe in Saudi Arabia. The /ts/ variant is an important sound, and it is the key feature in the phonetic inventory of the Anizi tribe because it is unique to this tribe. Its use is a defining characteristic of the tribe. This variant has not been studied and never been introduced, as far as I know, to the reader as it is used solely in its social context. Most of the studies conducted in the Arab world have concentrated on the anther affricate, namely the voiceless 
alveo-palatal affricate /C/. In this study, I have introduced the /ts/ variant as it is still used in some remote Bedouin areas in the heart of the desert. These areas are considered "relic areas" which means they exhibit similarities with respect to a particular feature and show evidence of a retention of old forms, as Mesthrie defines it (Mesthrie et al., 2000).

The study shows that this variant, unknown to numerous native speakers of Arabic, is still very active in the speech of the members of Anizi tribe. The older as well as the younger generations almost categorically use it, $99 \%$ and $90 \%$, respectively, within the tribal setting. The use of this variant dominates the speech of the people of this tribe, and, as such, its use is impossible to eliminate from their speech as it defines his / her own identity as a legal member of the group. A real Anizi must use the [ts] variant. Because it is not used by others outside the tribe, the Anizi vernacular which has the /ts/ sound has become difficult to be understood by non-members. Thus, an Anizi finds he / she must shift to use a more conventional variant, which is the $/ \mathrm{k} /$ in order to linguistically accommodate his / her interlocutor. Many informants stated that they shift to $/ \mathrm{k} /$ when they are involved in a conversation with non-/ts/ users in order to help them understand.

I believe the issue goes beyond semantic understanding to matters that are related to social meanings. In order to confirm that one is also part of the larger society one must abandon all that is very local and very unique to one's own tribal identity in conversations with non-Anizis. As it is obligatory to adopt the /ts/ to confirm one's identity within the tribe, it is also obligatory to abandon it to confirm another identity, one that is part of the larger society when outside the domain of the tribe. While the native variant is the /ts/, and as such it is unconsciously used, its abandonment is a conscious act. In other words, it is language planning but at the individual level.

\section{Acknowledgment}

The author would like to thank the deanship of scientific Research at King Faisal University (Saudi Arabia) for their financial support (Grant Number: 20176).

\section{References}

Abdel-Jawad, H. (1981). Lexical and Phonological Variation in Spoken Arabic in Amman. University of Pennsylvania dissertation.

Al Khatib, M. (1988). Sociolinguistic change in an expanding urban context A case study of Irbid city, Jordan. $\mathrm{PhD}$ thesis. University of Durham.

Al-Azraqi, M. (2014). Kaškaša and Kaskasa. Encyclopedia of Arabic Language and Linguistics. Managing Editors Online Edition: Lutz Edzard, Rudolf de Jong. Brill Online, 2014.

Al-Jehani, N. (1985). Sociostylistic stratification of Arabic in Makkah. PhD dissertation. The University of Michigan.

Daher, J. (1998). Gender in Linguistic Variation: The Variable (Q) in Damascus Arabic. In E. Benmamoun, M. Eid, \& N. Haeri (Eds.), Perspectives on Arabic Linguistics (vol. XI, pp. 183-205). Amsterdam: Benjamins Publishing Company. http://dx.doi.org/10.1075/cilt.167.13dah

Eckert, P. (1997). Age as a Sociolinguistic Variable. In F. Coulmas (Ed.), The Handbook of Sociolinguistics (pp. 151-168). Oxford: Blackwell.

El Salman, M. (2003a). Morphological and phonological variation in the speech of the Falahis in the Karak area. University of Durham (England) dissertation.

El Salman, M. (2003b). The Use of the /q/ Variant in the Arabic Dialect of Tirat Haifa. Anthropological linguistics, 45(4), 413-426.

El Salman, M. (2008). Social change triggers linguistic change in Tubnah (Jordan). The Journal of Humanities and Social Sciences, 16(2), 67-79.

Gee, G. (2011). An introduction to Discourse analysis-Theory and methods. New York: Routlegde.

Holes, C. (1991). Kashkasha and the fronting and affricization of the velar stops revisited: a contribution to the hsitorical phonology of the peninsular Arabic dialects. In A. Kaye (Ed.), Sematic Studies in honor of Wolf leslau (pp. 652-678). Wiesbaden: Harrassowitz.

Labov, W. (1966). The social stratification of English in NewYork City. Washington, DC: Center for Applied Linguistics.

Labov, W. (1972a). The Study of Language in its Social context. In J. Pride \& J. Holmes (Eds.), Sociolinguistics: Selected Reading (pp. 180-201). Middlesex: Penguin Book. 
Labov, W. (1972b). Sociolinguistic Patterns. Philadelphia: University of Pennsylvania Press.

Labov, W. (2001). Principle of Linguistic change (vol. 2). Oxford: Blackwell.

Le Page, R. (1997). The Evolution of a Sociolinguistic Theory of Language. In F. Coulmas (Ed.), The Handbook of Socio-linguistics (pp. 15-32). Oxford: Blackwell.

Milroy, J., \& Milroy, L. (1978). Belfast: Change and variation in an urban vernacular.

Myers-Scotton, C. (1995). Social Motivations for Code Switching: Evidence from Africa. Oxford: Clarendon Press.

Owens, J. (2013). Chapter 504 and modern Arabic dialetolgy: What are kashkasha and kaskasa, really? In C. Holes \& R. de Jong (Eds.), Ingham of Arabia. Leiden: brill.

Qassim, Y., \& Khaleel, A. (1996). Lahjat il karak. Karak: Mu'ta University.

Trudgill, P. (1974). The Social Differentiation of English in Norwich. Cambridge: Cambridge University Press.

Watson, J. (1992). Kashkasha with reference to modern Yemani dialects. ZAL, 24, 60-81.

Wieder, D. L., \& Pratt, S. (1990). On being a recognizable Indian among Indians. In D. Carbaugh (Ed.), Cultural communication and intercultural contact (pp. 45-64). Hillsdale, N. J.: Lawrence Erlbaum.

Note. The most significant symbols used in transcribing Arabic words are: /z/ glottal stop, /q/ voiceless uvular stop, /g/voiced velar stop, /t/ emphatic voiceless alveolar (or denti-alveolar) stop , /d/ emphatic voiced alveolar (or denti-alveolar) stop, / /voiceless interdental fricative, /ठ/ voiced interdental fricative ,/ Đ/ emphatic voiced interdental fricative, /ș/ emphatic voiceless alveolar fricative, /// voiceless alveolar fricative, /3/ voiced alveolar (or palato- alveolar) fricative, $/ \mathrm{d} / /$ voiced alveolar (or palato alveolar) affricate, $/ \dot{\mathrm{g}} /$ voiced velar fricative, $/ \hbar /$ voiceless pharyngeal fricative, / $\mathbf{f} /$ voiced pharyngeal fricative.

\section{Copyrights}

Copyright for this article is retained by the author(s), with first publication rights granted to the journal.

This is an open-access article distributed under the terms and conditions of the Creative Commons Attribution license (http://creativecommons.org/licenses/by/3.0/). 